\title{
防護動機理論に基づく自然災害リスク認知の パラドックスの検証
}

\author{
柿本 竜治 $1 \cdot$ 上野 靖晃 ${ }^{2} \cdot$ 吉田 護 3 \\ 1正会員 熊本大学教授 大学院自然科学研究科（干860-8555 熊本市中央区黒髪2丁目39-1） \\ E-mail: kakimoto@kumamoto-u.ac.jp \\ 2学生会員 熊本大学大学院自然科学研究科（†860-8555 熊本市中央区黒髪2丁目39-1） \\ E-mail: 143d8806@st.kumamoto-u.ac.jp \\ 3正会員 熊本大学特任准教授 大学院自然科学研究科附属減災型社会システム実践研究教育センター \\ ( ( $860-8555$ 熊本市中央区黒髪2丁目39-1) \\ E-mail: yoshidam@kumamoto-u.ac.jp
}

\begin{abstract}
「自然災害に対するリスク認知が高くても，そのリスクへの防護行動を取らない。」といった自然災害 リスク認知のパラドックスの存在が指摘されている. 自然災害リスク認知のパラドックスの存在は, 自然 災害リスクの認知を向上させるだけでは，そのリスクへの防護行動を促すことが難しいことを意味する. そこで, 本研究では, 既往研究の中に見られる自然災害リスク認知や減災意識と防護行動との乘離の要因 を抽出し，自然災害リスク認知パラドックスの存在を確認する. そして, 防護動機理論の枠組みを援用し て, 研究の視点や枠組みを整理することを通じて, 個人の自発的な減災行動の包括的な理解を促すことを 目的とする。また，同時に阿蘇市および南阿蘇村で実施された予防的避難の実行状況と自然災害への意識 の分析から意識と行動の乘離の要因を探る.
\end{abstract}

Key Words : natural disaster, risk reduction, risk perception, paradox, protection motivation theory

\section{1. はじめに}

頻発する自然災害に対し，行政のみで対策・対応を行 うことが困難であるという認識が広がる中，住民は自ら 減災対策・対応に取り組むことが求められている．政府 は減税措置（住宅而震改修特別控除，地震保険料控除な ど）や補助金交付（耐震診断・改修，自主防災組織設 立・活動など），災害関連情報の開示・普及（水防法の 改正, 2005; 土砂災害法の改正, 2014）などを通じて住民に よる自発的な減災活動を促している。一方で，災害への 関心は高まりつつあるものの，必ずしも実際の減災行動 に結びついていない，という課題が指摘されている122). この状況は，多くの実証研究が「自然災害に対する各 個人のリスク認知とそのリスクに対する個人の準備行動 や避難行動との間には関係性が低い」との指摘に符合し ている ${ }^{3)}$ 。また, Dash and Gladwin ${ }^{4} も$ ，避難意識と避難行 動との間に乘離があることを指摘している。これらは, 「自然災害に対するリスク認知が高くても，そのリスク への防護行動を取らない」といった自然災害リスク認知 のパラドックスの存在を示唆するものである. 自然災害
のリスク認知パラドックスの存在は，自然災害リスクの 認知を向上させるだけでは，そのリスクへの防護行動を 促すことが難しいことを意味する．住民の自発的な減災 行動をさらに促進させるためには，この乘離の要因を特 定し, その乘離を埋めるための諸方策を講じていく必要 がある。

本研究では，このような観点から既往研究の中に見ら れる自然災害リスク認知や減災意識と減災行動との乘離 を抽出し, 自然災害リスク認知パラドックスの存在を確 認する. それとともに，既往研究を包括的に概観し，研 究の視点や枠組みを整理することを通じて，個人の自発 的な減災行動の包括的な理解を促すことを目的とする. その際，Rogers ${ }^{5,0}$ のよって提唱されている防護動機理論 の枠組みに基づいて全体の整理を行う。防護動機理論は, 健康リスクへの個人の対処行動を説明する理論として広 〈知られており》，環境リスクタ)や情報セキュリティなど 多くの分野に応用されている. 本研究で対象とする災害 リスクーの対処行動を分析した事例もあり，その応用範 囲は広い. 既往の研究の全てが防護動機理論に則って行 われてはいないが，防護動機理論の枠組みを拡張するこ 
とにより, 既往研究の位置付けが明確になり, 個人の減 災行動を促す要因の考察を容易にする．最後に，防護動 機理論の枠組みに則った事例分析を行い，自然災害リス ク認知と減災行動の乘離の要因を探る. 事例分析の対象 地域は, 平成24年7月の北部九州豪雨の土砂災害により 23名の死亡者を出した阿蘇市および南阿蘇村である. こ の地域では，豪雨災害の経験を踏まえ，夕刻の時点で梁 夜に大雨が予想される際，明るいうちから避難を促す 「予防的避難」に取り組んでいる，その予防的避難の住 民の実行状況と自然災害への意識の分析から意識と行動 の乘離の要因を探ることをもう一つの目的とする.

\section{2. リスク認知と減災行動のパラドックス}

本稿では，社会経済的な文脈を統一寸るため日本国内 を対象とした減災意識や減災行動の研究の中から自然災 害や対策の知識，およびリスク認知が，減災行動意図や 実際の行動に結びついていないことに触れられてる事例 を取り上げる，それらの事例を通じて，自然災害リスク 認知のパラドックスの存在を確認する.

一般的に, 減災意識や自然災害への危機意識が高くな ると，減災行動の意図が高くなると考えられている．元 吉ら 9は, 地域と家庭における減災行動の規定要因の差 異に着目した研究の中で，日常から取り組める家庭内の 減災行動意図の規定には，リスク認知（発生可能性認知, 不安感）, ベネフィット認知（自己効力感, 反応効果性 認知）が影響することを結論づけている. 一方で，下記 に示寸ように減災意識や危機意識といった「意識」と， 減災行動といった「行動」は必ずしも整合しないことを 指摘している研究も多数存在する. 高尾ら ${ }^{10}$ は, 水害経 験や水害予測をもとに，水害に遭った場合や近い将来水 害が起こるかもしれないという危険性は感じても，それ を動機として避難袋の準備や保険加入といった減災行動 にはなかなか結びつかないことを明らかにしている。 ま た，上市・楠見 ${ }^{11}$ も地震災害のリスクを認知していても， 避難経路の確認や非常持ち出し品の準備などに結びつい ていないことを示している. 今本ら ${ }^{12} は$ は, 水害一の危険 性の関心が高くとも，必ず非常品の備えを行っているわ けではなく，「憂いあれど備えなし」の状況があると指 摘している. また，住民の減災意識は高いものの平常時 の対応や避難行動と言った実際の行動を行っていない傾 向がみられることを明らかにしている ${ }^{13)}$. 原岡ら ${ }^{14}$ は, 危険という意識より，災害に対する知識がある者が，平 常時の災害に対する備えをしていると指摘している。 こ のように自然災害リスク認知と自然災害への備えの間に 乘離があることが確認される。

斉藤 ${ }^{15}$ は, 1989 年の三陸沖地震発生時の住民の意識
と避難行動の分析において, 強い不安感があったとして も，自宅が危険ではないと判断した場合避難していなか ったことを明らかにしている. また，古山・和田 ${ }^{10}$ は, 2011 年の紀伊半島大水害の際，避難せず，被災もしな かったが孤立した集落において，災害に対する不安が高 くても避難する時期が他の集落より遅いか自宅に止まる 割合が高かったことを指摘している，木下ら ${ }^{17} は$, 災害 時の避難行動プロセスを沖縄県中城村の地すべり災害を 例にとったアンケート調査結果において, 住民が避難す るには，災害に関する知識よりも，避難勧告・指示につ いての知識が強く影響すると結論づけている. このよう に自然災害の知識やリスク認知と避難行動意図や避難行 動との間にも乘離があることが確認される.

個人が自然災害の被災経験や避難経験を有している場 合，その経験則により，自然災害リスク認知が高まり， 災害に対する自衛策を講じることや避難行動に結びつく ことが多くの調查研究で報告されている ${ }^{18)}$. また, 直接 的被災経験がなかったとしても地域住民間の伝承 ${ }^{19)}$ や減

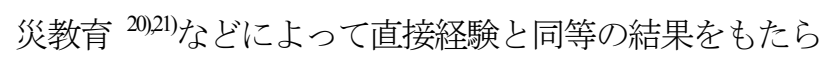
すことも報告されている. しかし, 被災経験が避蜼行動 を促さない場合もある，及川・片田22は，過去の自然災 害の被災経験で被害が小さかった場合は，その経験に基 づき，その後発生し得る事象を軽視する傾向にあり，災 害に対する务威評価が低下し避難行動意図が高まらない ことを実証している．山田・柄谷 ${ }^{23}$ は，被害経駼があり， 水害に関する知識を有していると, 水害リスク受容が高 い傾向にあるが，水害リスク受容が高い住民が必ずしも 日常の対策をしているわけではないことを指摘している. このように被災経験が，災害時の避難行動を促すとは限 らないことが示されている.

減災行動における行動意図と実際の行動には乘離があ ることを指摘しているものもある。諫川ら ${ }^{24}$, は，東日 本大震災前後に千葉県御宿町で避難意識と避難行動に関 するアンケート調査を実施したところ, 震災前の調査で 約 9 割の住民が地震・津波が発生した際は避難すると回 答していたが，実際の震災時に避難行動を取った住民は 4 割に満たなかったと報告している。 また，片田ら ${ }^{29}$ は 住民の行政依存に着目したアンケート調査結果で, 非常 持出袋等の準備は住民個々で行うべきであると回答して いるものの，実際に非常持出袋等を準備している住民は 少なかったと報告している.

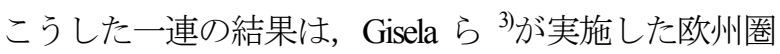
の事例を対象とした文献レビューの結果とも整合的であ る. 減災に対する関心が高くても減災行動に対する住民 の負担感が高い場合，実際の行動につながらないことは, 防災白書の中でも報告されている ${ }^{2)}$. 吉森ら 20や上市・ 楠見 ${ }^{11)}$ の研究において, 減災行動に伴うコス卜 (心理的 コスト含む）が，減災行動の阻害要因との指摘があるよ 
うに，自然災害リスク認知とあわせて減災行動に伴うコ ストを考慮することが災害リスク認知と減災行動の間に 生じるパラドックスを解消するための第一の諸方策かも しれない. 自然災害のリスク評価を含む「劦威評価」と 減災行動に伴うコストを含む「対処評価」という二つの 要因の影響を考慮してリスク回避・軽減行動を分析寸る ための心理モデルの一つに防護動機理論がある 5,0.

そこで, 次章では, 防護動機理論の主要構成要素であ る劦威評価，対処評価を核として，既往文献における減 災行動意図や実際の減災行動の分析結果を踏まえて, 自 然災害リスク認知と減災行動（意図）の間に生じるパラ ドックスの要因を探る枠組みを整理する.

\section{3. 防護動機理論に基づく減災行動要因の整理}

\section{（1）防護動機理論の基本的枠組み}

防護動機理論は，リスク回避・軽減行動を分析するた めの心理モデルであり, 务威評価と対処評価によって 「防護動機」が形成されると仮定している．そして, 「防護動機」が高いほど「防護行動」を実践するとされ ている. 劦威評価は，具体的には，深刻さ認知（被害の 大きさに関する認知），生起確率認知（被害の生じる確 率についての認知），外的報酬認知（防護行動を取らな いことから得られる他者からの賞賛などに関する認知）, 内的報酬認知（防護行動を取らないことによる身体的快 感や満足感に関する認知）の四つの認知的要因から形成 され，それぞれ独立した要因であることが仮定されてい る.また，恐怖は対処行動意図に直接的には影響はなく， 深刻さ認知を通じて対処行動動機に間接的に影響を及ぼ すことを仮定しているものもある ${ }^{927}$. そこで，本研究 では，恐怖も劦威評価を形成する認知的要因とする.

対処評価については, 反応効果性認知（特定の対処行 動を行った場合に当該の被害をどれだけ避けることが出 来るかに関する認知），反応コス卜認知（対処行動を行 うことによる金銭的，精神的コストに関する認知），自 己効力感（行動を自身で実行できる自信や見通しなどに 関する認知）の三つの要因から形成され，それぞれ独立 した要因であることを仮定している。この脅威評価と対 処評価によって防護動機が形成されるとするのが防護動 機理論の基本的枠組みとなる，なお，個人の減災行動に 応用するにあたって, 脅威評価の内的・外的報酬認知は 考慮しない. 内的・外的報酬認知について減災行動の文 脈においては，減災行動に必要な（人的・経済的）資源 を他の活動に利用寸ることによって得られる内的・外的 な報酬と解釈可能であり, 反応コス卜認知を機会費用の 認知と解釈することにより省くことが可能である ${ }^{28}$. そ のため, 内的・外的報酬認知については劦威評価の構成
要素から省くこととする.

また, Rippetoe and Rogers ${ }^{27}$ は, 务威を感じているが対 処行動を取らない場合, 人は非防護反応を示し, 非方護 反応そのものも対処行動の動機を妨げるとしている．防 護動機理論と非方護反応の関係性については多くの研究 がなされており 29,30)，非防護反応には，当該の危険につ いて考えないようにする思考回避や劦威による危機の可 能性を認めない否認, 運命だと諦める運命諦観, 何とか なると楽観的になる楽観視，どんなに防災・減災に取り 組んでも無意味だと思うなど, 自然災害に対応すること 自体を否定する絶望, 祈りをささげる信仰などが挙げら れる. 本研究では, こうした非放護反応も個人の減災行 動を説明するための主要因と捉えることとする.

务威評価, 対処評価, および非訪護反応によって説明 される行動意図と行動は, 防護動機理論においてしばし ば同一視されてきた。これは，行動意図と実際の行動の 相関が高く ${ }^{31)}$, 行動意図が実際の行動を説明する最も強 い予測変数であったことによる ${ }^{32,33)}$. しかし, 行動意図 と実際の行動の間には，乘離があるという指摘もされて おり ${ }^{34)}$, 個人の減災行動の文脈においても, 前述したよ うに，避難しようと考えていた住民が必ずしも避難行動 をとっていないなど，行動意図と実際の行動の間には乘 離があることが報告されている，そのため，本研究にお いては, 減災行動意図と実際の減災行動は区別して捉え ることとする.

\section{（2）個人の減災行動に影響する諸要因}

上記に説明した防護動機理論の構成要素である脅威評 価, 対処評価, および非方護反応は, 個人の減災行動を 説明する心理的要因として位置付けられる. その上で, 個人の減災行動を説明する他の諸要因を既往研究から抽 出し, 分類した. 具体的には, 社会人口統計学的要因, 地理的・空間的要因, 経験, 信頼, およびユミュニケー ションの5つに分類した. 図-1に本研究の防護動機理論 に基づく減災行動意図と減災行動モデルの枠組みを示寸. 以下では，それぞれの要因が個人の減災行動意図と減災 行動に及ぼす影響について既往研究を概観する.

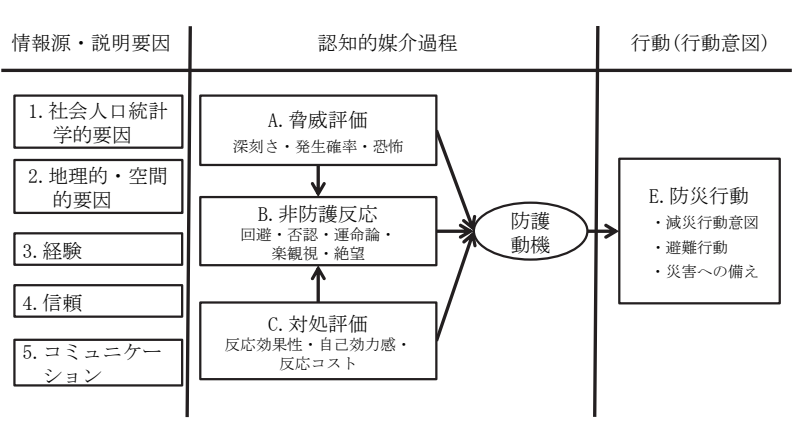

図-1防護動機理論に基づく減災行動モデルの枠組み 


\section{a) 社会人口統計学的要因}

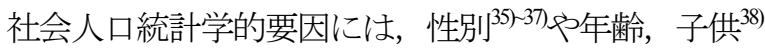
高齢者の有無等の家族構成，家屋の所有形態283399)，教育 水準 ${ }^{40,41)}$, 居住年数 ${ }^{41)}$, 配偶者の有無, 人種，宗教など が含まれる，こうした要因は，社会階層が個人の減災行 動に影響を及ぼすことを示唆する場合もあり，問題視さ れる場合もある，高尾ら ${ }^{10}$ は，家屋の所有形態と減災意 識および減災行動との関連性について分析し，持ち家住 民の方が借家住民に対して減災行動をとる住民の割合が 高いなど様々な違いが認められたと報告している．氏原 ら ${ }^{42}$ は，津波非常襲地域の居住者を対象に，津波防災一 の備えの傾向を「思考」を伴う対策，「行動」を伴う対 策，「知識」を伴う対策のうちどの対策を行っているか は，個人・世帯属性と関係していることを指摘している。 しかし, 社会人口統計学的要因と個人の減災行動との関 連性は見られなかったとする研究も多く，世界及び地域 共通の見解が得られているとは言い難い現状にある。た だし, 災害の脅威に直面した避難行動は, 家族単位で行 われる場合も多く22)43745)，家族や高齢者の有無など家族 構成も減災行動に重要な影響を与えうることに留意が必 要である.

\section{b) 地理的 · 空間的要因}

地理的・空間的要因は，ハザードの空間的分布，避難 所などの防災関係施設の立地場所や居住地に関係寸る要 因である. 多くの既往研究が, 対象とする地域, 対象と 寸るハザードを絞った上で調査を行っているが，住民が 曝されているハザードの頻度や強度は住民毎に異なって いる，例えば，Siegrist and Gutscher ${ }^{40}$ は，郵送調査を通じ て，居住地によって異なる専門家の水害リスク評価と住 民の水害リスク認知との間に正の相関があることを示し ている. また, 海岸からの距離や自宅から避難所までの 距離など, 空間距離は個人の避難行動を理解する上で重 要である. 細井ら ${ }^{47}$ は, 名古屋市南部の臨海部の住民を 対象とした減災意識の調査で，対象地域は海岸に最も近 い地区で地盤高が最も高いにも拘わらず，海岸から遠ざ かるにしたがってゼロメートルより高いと回答した人の 割合が多くなっており，海岸からの距離が危険意識に影 響していることを指摘している. 宮瀬・菊井 ${ }^{48}$ は, 熊本 県水俣市宝河内集地区での土砂災害事例で，低地の住民 の多くは，土石流が発生する前に家屋浸水などにより危 険を感じたため避難していたが，高台の住民は，高台の ため安全であると考え避難せず被災したと指摘している。 諫川ら ${ }^{24}$ は，地震発生後の行動は，地震時にいた場所に よって大きく異なり，自宅以外の場所にいた場合，迅速 な避難が行われにくかったことを指摘している.

このように住民が曝されている八ザードやその関心の 度合いは居住地によって影響する。 八ザードに関する科 学的な情報とその劦威の深刻さや発生頻度に関する住民
の認知の間には乘離があるそその乘離を埋めることは， 住民の過度または過小な減災行動を抑制するための重要 な処方策の一つと考えられる. また，複数のハザードの 脅威に曝されている地区もあり，このような地区の住民 の減災行動を理解し，促進するためには，八ザード固有 の特徵とその空間分布を考慮することが必要になる.

\section{c) 経験}

経験が個人の減災行動意図や減災行動に及ぼす影響に ついては膨大な研究蓄積がある. 被災経験がリスク認知 を高めるとする論文は，国内外問わず数多く見られるが， 行動意図や実際の行動に結び付くかについては見解が分 かれている. 災害は発生したがそのとき個人的には被害 を受けなかった住民は比較的リスク認知が低いとする見 解は多く, Ruin $5^{49}$ は, 水害の文脈において過去直接水 害を経験した個人は，危険を過大評価し，未経験の個人 は過小評価する傾向にあることを示している，また，土 砂災害においても経験者は，災害発生の頻度，命の危険， 恐怖を未経験者と比較して高く認知しているとする研究 結果を示している. 及川・片田22)は, 洪水に対する避難 開始時期の意向は，過去の洪水被害が比較的中 ・ 小規模 であった住民は不安になる時期は早いものの避難決定時 期や避難開始時期が遅くなる傾向にあり，一方，洪水被 害が大規模であった住民は早くなる傾向にあることを指 摘している．また，大本ら ${ }^{18)}$ は，過去の災害の被災経験 よりは，災害時に避難をしたことがあると避難する傾向 にあることを指摘している. 被災経験といっても人的被 害の経験から地震や土砂㷋害における家屋の倒壊被害, 水害における床上浸水など，その特徵は様々である. 災 害の特徵や個人の被災経験の文脈の考慮は, 経験が個人 の減災行動に及ぼす影響のさらなる理解を促すものと考 えられる。

\section{d) 信頼}

ここで信頼とは，主に政府や専門家への信頼であり， 堤防やダムなどの構造物的対策や警戒・避難情報の発信 などの情報対策の文脈で，それぞれ個人の減災行動に影 響を及ぼすことが指摘されている．構造物的対策がリス ク認知や減災行動に与える影響について, 水害の発生頻 度や被害の大きさを減少させる堤防やダムへの信頼は, 結果として個人の減災行動を阻害するという指摘50)がな されている. 一方で, 堤防に守られていない住民も水害 リスクを過小評価寸るという指摘51)もる。 これは, 政 府は住民の資産を水害から守る責任があるという住民の 政府に対する過度の信頼によるものである，避難情報に ついて, 片田ら ${ }^{52}$ は, 東海豪雨災害時の住民の避難行動 に際して, 避難勧告情報の取得の有無が避難率や避難開 始タイミングに大きく影響を与えていたことを指摘して いる. また，避難勧告の空振りは情報の信頼性を低下さ せ，才オカミ少年効果を生む可能性の指摘もある ${ }^{53-50) . ~}$ 
構造物対策および情報対策への信頼は，どちらも避難遅 れを生じさせる原因であると考えられており，住民は政 府の構造的対策や情報政策の限界を理解，把握した上で, 自ら減災行動をとる必要があることを示唆している.

近年，西欧諸国では，個人やコミュニティが自分自身 で責任を負わなければならない場面が増えてきており57, これは日本の自助, 共助, 公助と協働・連携概念と通じ るものがある. 寸なわち, 政府への過度な信頼は, 減災 対策の政府一の依存を生むため, 個人の減災行動を阻害 する要因となる. 政府の人的，経済的資源の制約から， 注意報・警報発令時や災害発生直後などは，特に政府に 依存できない期間が存在することも事実である。このた め，政府は自ら災害対策の能力上の制約があることを明 確にし，その点を住民に理解してもらう必要がある. 日 本においてはこの問題を信頼の問題と捉えるのではなく, 住民の行政一の依存の問題として捉える場合が多い20158) が，行政と住民の適正な役割分担とその共通認識の形成 を通じて，個人の減災行動を促寸必要がある.

\section{e) コミュニケーション}

Siegrist and Gutscher ${ }^{40}$ は，住民が減災行動として何をす べきか知らなかったことがリスク認知と行動のギャップ を生じさせた一因であることを指摘している．また，火 山災害の文脈においても知識の欠如が個人の減災行動を 阻害する一因であることが指摘されている ${ }^{59,600}$. 日本に おいては，木下ら ${ }^{17}$ が避難先を知っている住民ほど避難 傾向にあることを示しているほか，八ザードマップを用 いた減災教育 ${ }^{20) 611}$ や地域の災害伝承 ${ }^{(2)}$ などを通じて住民 に知識を付与することが，リスク認知や減災意識の向上 に寄与することを示している，一方で，知識を持ってい てもリスク認知や減災行動に影響を与えない可能性も指 摘されており, 諫川・村尾 ${ }^{(3)}$ は, 過去発生した地震に関 する知識をもっていたとしてもリスク認知に寄与してい ないことを示している. また, 避難勧告や避難指示の意 味を理解していない住民が少なからずいることも指摘さ れている ${ }^{(4), 65)}$. 行政もしくは専門家は, 住民とのリスク コミュニケーションを通じて, 住民の劦威評価や対処評 価に働きかけることが出来る．信頼性の高い政府や専門 家からの情報はリスク認知を高め, 実際の行動に影響を 与えることが示されており ${ }^{50}$, 対話的なリスクコミュニ ケーションの有效性が指摘されている ${ }^{60}$.

\section{4. 避難意識の促進と阻害要因}

\section{(1) 予防的避難に関するアンケート調査概要}

平成24年7月の北部九州豪雨災害では，深夜の記録的 な豪雨による土砂災害で阿蘇市を中心に 23 名が死亡した。 熊本県は, この経験を踏まえ, 夕刻の時点で深夜に大雨
が予想される際, 明るいうちから避難を促す「予防的避 難」の取組みを, 北部九州豪雨災害で甚大な被害を受け た阿蘇市と南阿蘇村で平成25年度より始めた。甚大な被 害を受けた翌年であったが，平成25年に実施された予防 的避難5回でのべ133世帯，368人と少なかった。 そこで, 予防的避難の阻害要因や促進要因を探り出寸ために, 平 成26年の1月8-24日に避難意識に関寸るアンケート調査 を阿蘇市 9,752 世帯および南阿蘇村4,177世帯の全世帯を 対象に行った. アンケート調查票は，阿蘇市および南阿 蘇村の各区長が戸別に配布し，郵送で回収した．回収率 は, 阿蘇市3,522件, 南阿蘇村1,280件の計4,802件で, 36\%であった. そのうち「予防的避難」の取組みについ て知っているとの回答は，81\%であった. アンケート票 では，性別，年齢，災害の経験や避難経験，予防的避難 の実施意図や実施の有無, 务威評価に関する項目, 非方 護意識に関する項目および対処評価に関する項目につい て質問している67．なお，文献67)では，予防的避難の阻 害要因と促進要因の抽出を試みているのに対し, 本稿は 避難意図と避難行動の乘離に着目している. また，防護 動機理論の枠組みに基づく減災行動に関わる要因をモデ ルを図-1のように整理しているが，信頼，コミュニケー ションに関する項目については，今回のアンケートでは 調査していない. また, 社会人口統計学要因については, 回答者の性別, 年齢以外の項目のデータが十分ではない. 今回の自然災害リスク認知と減災行動（意図）の間に生 じるパラドックスを探る枠組みにおいて, これらの要因 は未検討である点は申し添えておきたい.

まず，平成25年に5回実施された予防的避難の呼びか けに，「少しは避難しようと思った」以上の避難意図は あることを回答した 1,427 人の実際の避難割合を図-2に示 す.必ず避難しようと思ったグループの $49.5 \%$, 避難し ようと思ったグループの $39.2 \%$ ，少しは避難しようと思 ったグループの $13.7 \%$ が，実際に予防的避難行動を行っ ている．避難意図の高さが実際の避難行動に繫がってい ることが分かる. 一方で, 必ず避難しようと思った人の 50.5\%が避難しなかったように, 避難意図が高いからと いって, 必ずしも避難するとは言えないことが分かる.

次節では, 避難意図および避難行動とそれらに影響す ると思われる項目との関係を分析するが，本アンケート 調査では，务威評価および対処評価に関する項目につい ては, 4 パターンの予防的避難の呼び掛けの 1 つをラン

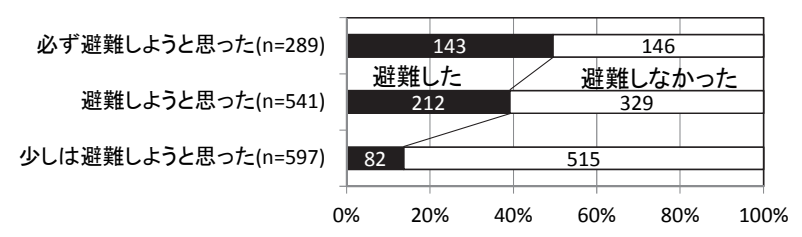

図-2 予防的避難の避難意図と避難行動の関係 
表-1 予防的避難の呼び掛けパターン 1

夜から明け方にかけて激しい雨が降る恐れがあります。自 主避難所を開設しましたので，避難される方は食事や毛布 等をご淮備のうえ，明るいうちに避難されるようお願いし ます。

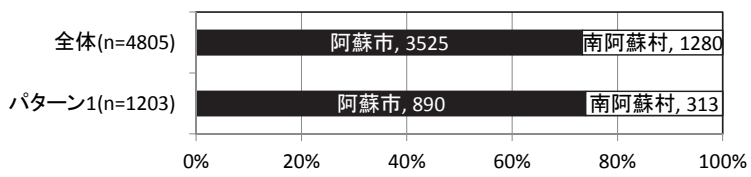

図-3 地域構成割合の比較
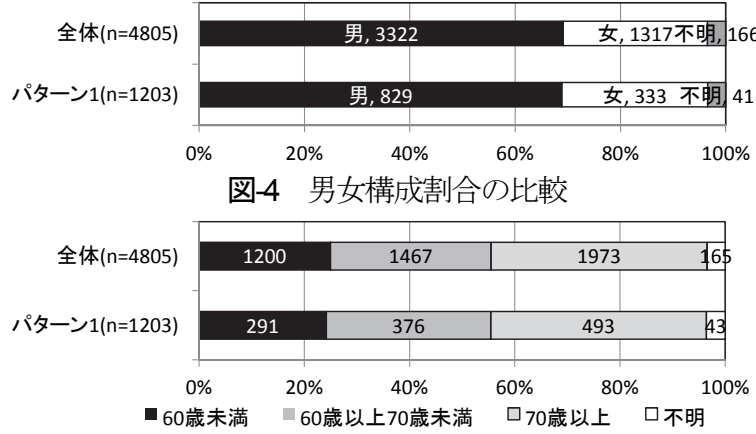

図-5 年歯構成割合の比較

ダムに示した回答となっており，実際の呼び掛けとは異 なる表現を用いている場合がある，呼び掛けの表現の影 響を除くため，表-1 に示寸実際の予防的避難の呼び掛 けと同じパターン 1 の表現を提示したサンプル 1,203 件 のみを分析対象とする. サンプルリングによる偏りがな いかをチェックするため，全サンプルとパターン 1 のサ ンプルの地域構成割合，男女構成割合，年齢構成割合を 比較したものを図-3，図-4，および図-5 にそれぞれ示す． これらの図より，地域構成割合，男女構成割合，および 年齢構成割合の寸べてにおいて，全サンプルとパターン 1 のサンプルの間で差異がないことが確かめられる.

このアンケート調査は，平成25年に5回実施された予 防的避難の呼び掛けの後に行っている. そのため，各種 認知とそれに基づく行動の時系列が整合していないが, 平成25年中に災害の発生はなく，予防的避難の呼び掛け 前後での災害の生起確率認知や被害想定の深刻さ認知等 の変化は小さいものとして以下の分析を進める.

\section{（2）脅威評価と避難意図と避難行動}

予防的避難に関するアンケート調査の中で，务威評価 の形成要因については，水害もしくは土砂災害に関する 深刻さ認知，生起確率認知，および恐怖認知の3つを聞 いている．深刻さ認知については，洪水や土砂災害で被 害を受けたら家屋の被害はどの程度になるかを5段階, 生起確率認知については，自宅が水害もしくは土砂災害 による被害を受ける確率について5段階，恐怖認知につ いては，予防的避難の放送を聞いたときに身の危険を感 じるかについて4段階で回答してもらっている，劦威評

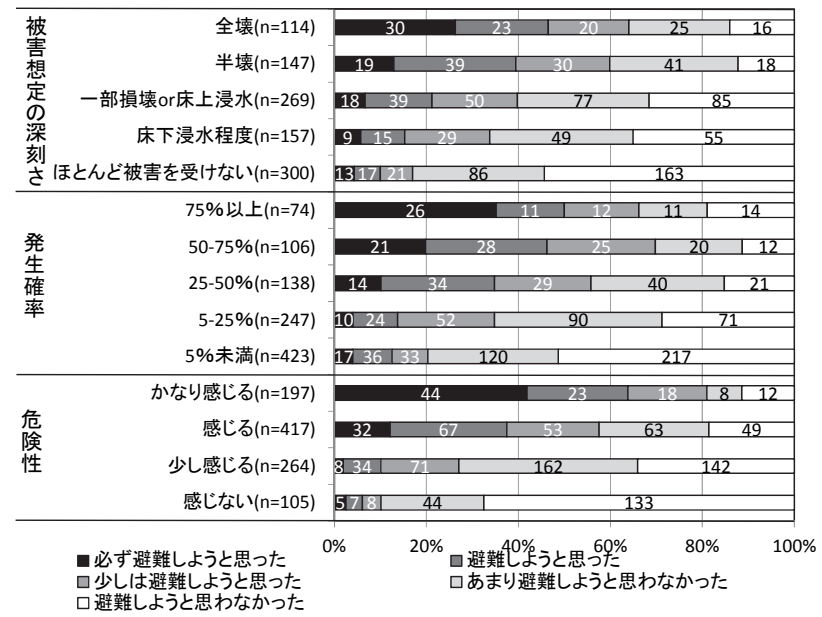

図-6 务威評価と避難意図

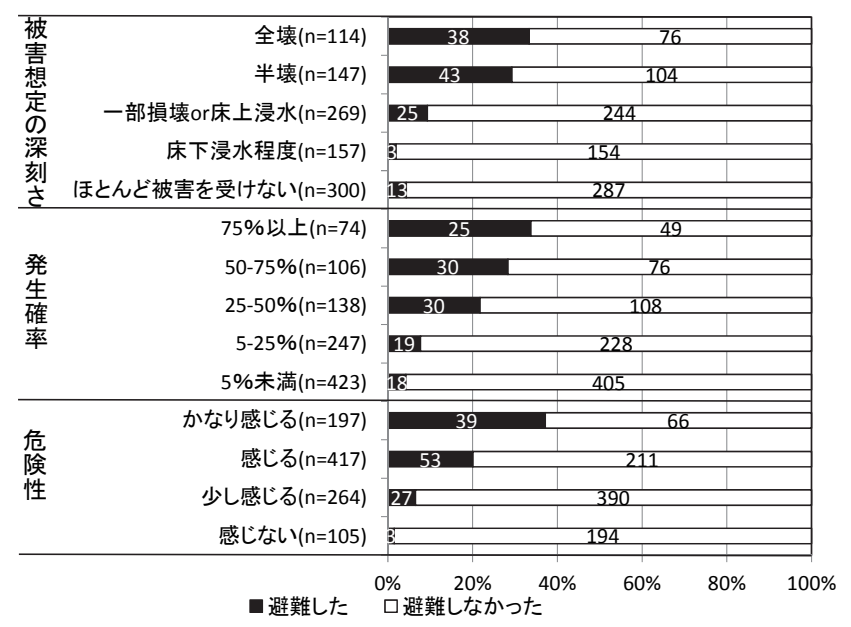

図-7 脅威評価と避難行動

価の要因と避難意図および避難行動の関係を図-6, 図-7 に示す．被害想定の深刻さの認知が大きい，主観的な災 害発生確率の認知が高い，また，災害の危険性を強く感 じたグループほど避難をしようと思っていた人，および 実際に避難した人の割合は多くなっている。しかしなが ら，災害の生起確率認知については，そもそも災害の発 生確率を高く想定している人自体が少なく，発生確率が 50\%以下のグループの方が多くなっている。「被害想定 の深刻さ」が高いグループ (全壊，半壞）や「災害の危 険性」を強く感じたグループ（かなり感じる，感じる） でも「必ず避難しようと思った」や「避難しょうと思っ た」人は半数以下である. ただし, 実際に避難した人の ほとんどは，「被害想定の深刻さ」が高い人たちや「災 害の危険性」を強く感じた人たちである.

以上のことから，避難をしようと思った人や避難した 人たちの多くは，「被害想定の深刻さ」，「災害の発生 確率」,「災害の危険性」の内の $1 つ も し く は$ 複数を高 く評価した人である。しかしながら，务威評価の項目の 評価が高いからといって，避難意図が形成されたり，実 際に避難するとは限らないことが確認される。すなわち， 
自然災害のリスクを認知していても避難行動を取らない 人が存在していることが確認される.

\section{（3）非防護反応と避難意図と避難行動}

非防護反応の要因に関して，予防的避難に関するアン ケート調査の中では, 自然災害での被災の運命諦観, 自 然災害での被災の楽観視，自然災害対策への絶望の3つ を聞いている. 非防護反応の各要因と避難意図および避 難行動の関係を図-8，図-9に示す.

自然災害での被災を運命的に捉えている人や楽観視し ている人，自然災害への災害対策を絶望視している人は 少なく, また, 運命諦観, 楽観視, 絶望の大きさと避難 行動意図の形成や実際の避難行動の間の関係性はあまり 見られない，この事例では，避難行動意図の形成や実際 の避難行動への非放護反応の影響は小さいようである.

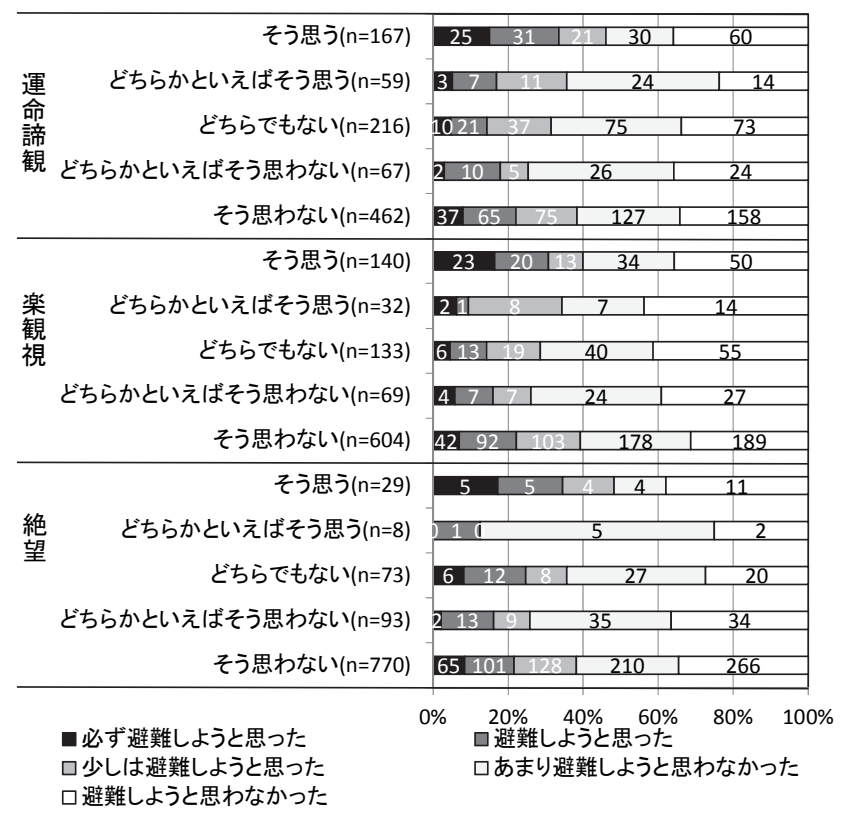

図-8 非防護反応と避難意図

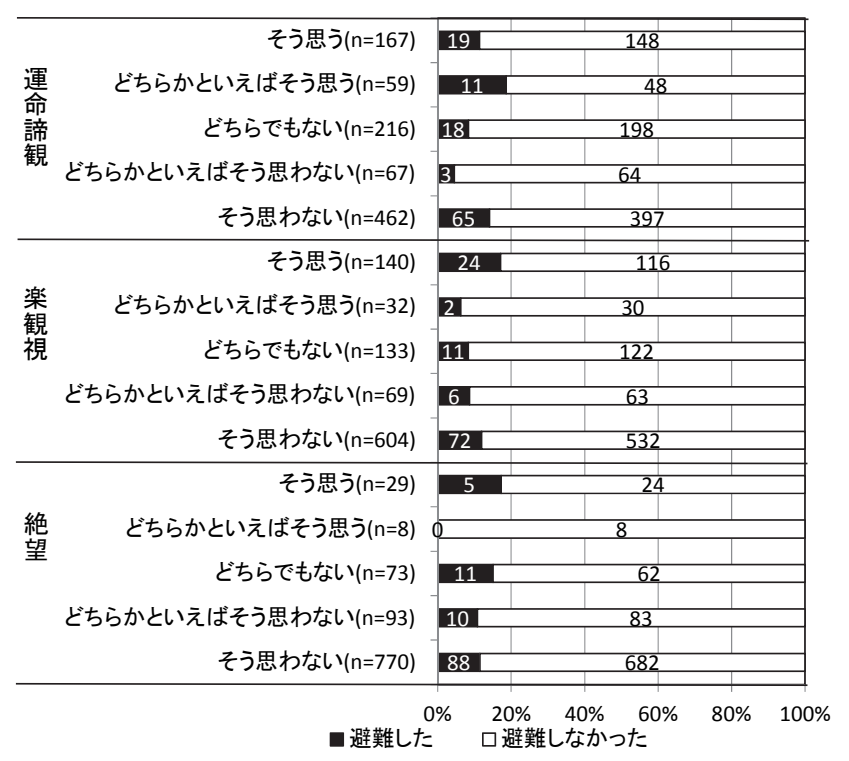

図-9 非防護反応と避難行動

\section{（4）対処評価と避難意図と避難行動}

対処評価については, 避難を行うことの反応効果性, 自己効力感と反応コストについて聞いている. なお，反 応コストについては, 避難淮備の面倒さ, 避難移動の面 倒さ, 避難所生活の不快さ, 自宅を留守にする不安の 4 つの避難することに対する心理的なコストを聞いている. 対処評価の各要因と避難意図および避難行動の関係を図 -10, 図-11に示寸.また, 対処評価の各項目についてそ う思う側かそうでないかの 2 グループに分けて，避難意 図の有り無し，および避難したか，しなかったとの関係 を $\chi^{2}$ 検定した結果を表-2に示寸.

「予防的な避難は身を守るのに効果がある」との反応 効果性一の回答の $93 \%$ 以上が，「そう思う」もしくは 「どちらかと言えばそう思う」であり，予防的避難の効 果について否定的な人は少なく, また, 否定的な人の中 に避難を実行している人はいない. 統計的検定結果から 予防的避難の効果を高く評価している人は，避難意図を 持つ傾向にあるが，実際の避難行動についてはそれほど 有意ではない.「他の人が避難しなくても自分で予防的 避難をすることができる」とする自己効力感が高いグル ープは，そうでないグループより避難しようと思った人 や実際に避難した人が多い。これは，表-2の統計的検定 結果からも確認される. 避難準備や避難所一の移動につ

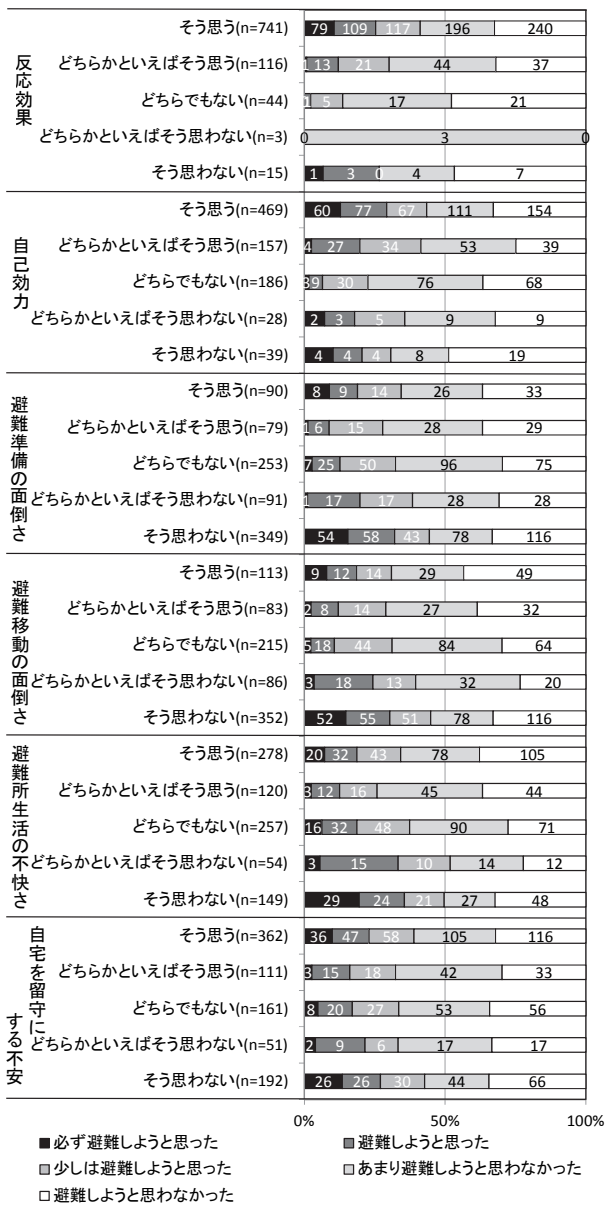

図-10 対処評価と避難意図 


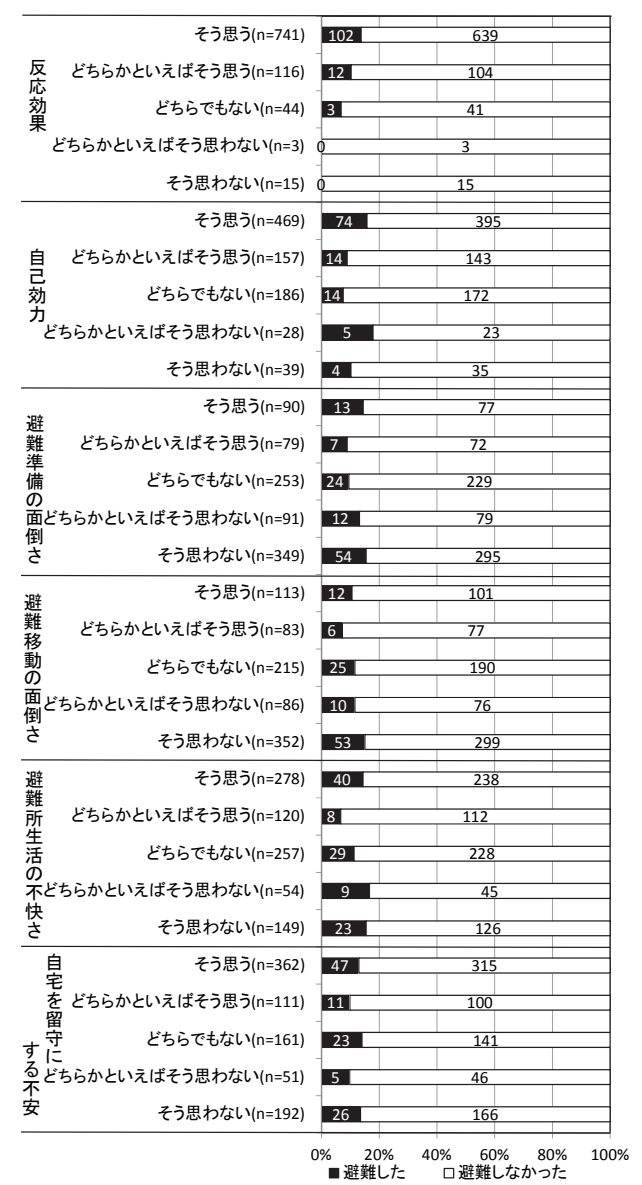

図-11 対処評価と避難行動

表-2 対処効果と避難意図・行動の検定結果 $\left(\chi^{2}\right.$ 值 $)$

\begin{tabular}{|l|c|c|}
\hline \multicolumn{1}{|c|}{ 対処効果の項目 } & 避難意図 & 避難行動 \\
\hline \hline 反応効果 & $13.57^{* * *}$ & $3.74^{*}$ \\
\hline 自己効力 & $23.85^{* * *}$ & $3.99^{* *}$ \\
\hline 避難淮備の面倒さ & $3.59^{*}$ & 0.17 \\
\hline 避難移動の面倒さ & $5.87^{* *}$ & 2.56 \\
\hline 避難所生活の不快さ & $11.77^{* * *}$ & 0.29 \\
\hline 自宅を留守にする不安 & 0.02 & 0.02 \\
\hline
\end{tabular}

$*$ : 有意水準 $10 \%$, ** : 有意水準 5\%, $* *$ : 有意水準 $1 \%$

いては，面倒だと思わないグループは，そうでないグル ープより避難しようと思った人の割合が多い．また，避 難所生活を不快と思わないグループも避難しようと思っ た人の割合は高かった．しかし，それらの項目について， 避難した人の割合は若干多いに過ぎず，統計的には. グ ループ間で実際の避難傾向に差があるとは言えない．最 後に, 避難のため自宅を留守にすることを不安視するグ ループとそうでないグループで，避難しようと思った人 や実際に避難した人の割合にそれほじ差はなかった。

避難意図の高い人は，自己効力感が高い，もしくは避 難に伴う心理的コストも低い傾向にある。しかし，実際 に避難している人については, 避難に伴う心理的コスト との間に明確な関係性は見られない。避難意図と避難行 動の乘離の原因の一因として, 避難に伴う心理的コスト の作用の仕方の違いが考えられる.

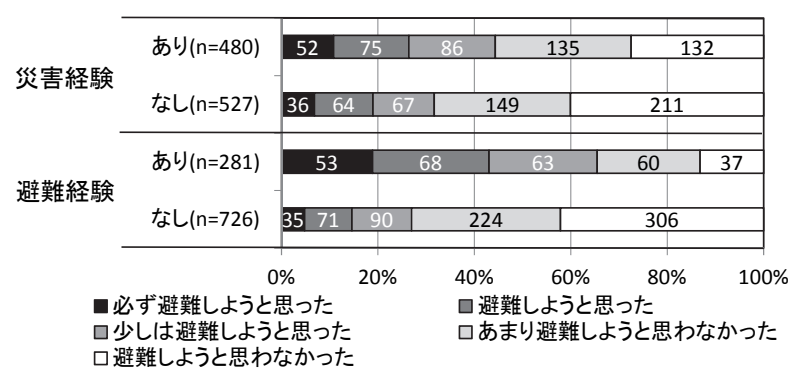

図-12 災害・避難経験と避難意図

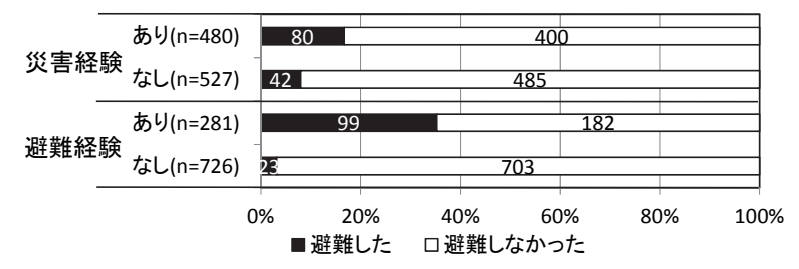

図-13 災害・避難経験と避難行動

\section{（5）災害経験，地理的要件と避難意図と避難行動}

アンケート調查では, 個人の減災行動に影響する諸要 因に関しては, 個人属性, 世帯構成以外に, 災害経験, および避難経験の夕聞いている. 災害・避難経験と避難 意図および避難行動の関係を図-12，図-13に示す。

「災害経験」のあるグループほど避難をしようと思っ ていた人，および実際に避難した人の割合は多い，しか しながら，災害経験ありのグループでも，少しは避難し ようと思った人を含めて避難しようと思った人は $44.4 \%$ にすぎない。また，実際に避難した人に至っては， 16.7\%とかなり少ない。「避難経験」についても，同様 に「避難経験」のあるグループほど避難をしようと思っ ていた人，および実際に避難した人の割合は多い，ただ し，避難した人の $81.1 \%$ 「避難経験」ありの人であり， 避難した人の多くは避難経験者である. しかしながら， 避難経験者の $64.8 \%$ は避難しておらず，避難を経験して いるからといって避難するとは限らないようである.

最後に地理的要件と避難意思, 避難行動の関係を見て みる. アンケート調査に回答した 4,802 世帯中 1,169 世 帯の方が詳細な住所を記入していた. 危険区域に居住し ているか研かは，予防的避難の呼び掛けのシナリオに関 係ないので，この 1,169 世帯の回答すべてを用いる. そ れらの住所と洪水ハザードマップの浸水想定区域および 土砂災害八ザードマップの土砂災害危険箇所，土砂災害 警戒区域，土砂災害特別警戒区域を地図上にプロットし， 危険区域に居住している世帯とそうでない世帯に区分し た. 危険区域に居住している世帯は，浸水想定区域，も しくは土砂災害八ザードマップの土砂災害危険箇所，土 砂災害警戒区域, 土砂災害特別警戒区域に住宅が立地し ている世帯とした．危険区域に居住している世帯は, 430 世帯が該当した. 居住地の危険性と避難意図および 避難行動の関係を図-14に示寸. 
表-3 避難意図および避難行動モデルの推定結果

\begin{tabular}{|c|c|c|c|c|c|c|c|c|}
\hline \multirow{2}{*}{ 変数 } & \multicolumn{4}{|c|}{ 避難意図 } & \multicolumn{4}{|c|}{ 避難行動 } \\
\hline & 推定值 & $\mathrm{t}$ 値 & 推定值 & $\mathrm{t}$ 值 & 推定值 & $\mathrm{t}$ 值 & 推定值 & $\mathrm{t}$ 值 \\
\hline 定数項 & -5.325 & $5.371^{* *}$ & -3.824 & $11.412 * *$ & -5.809 & $5.837 * *$ & -4.327 & $9.817^{* *}$ \\
\hline 災害経験 & -0.089 & 0.341 & - & - & -0.139 & 0.421 & - & - \\
\hline 避難経験 & 1.105 & $4.332 * *$ & 1.053 & $4.722 * *$ & 2.293 & $6.581^{* * *}$ & 2.240 & $7.391^{* *}$ \\
\hline 運命諦観 & -0.019 & 0.067 & - & - & 0.499 & 1.484 & - & - \\
\hline 楽観視 & 0.169 & 0.699 & - & - & -0.042 & 0.137 & - & - \\
\hline 絶望 & 0.297 & 0.750 & - & - & 0.484 & 1.093 & - & - \\
\hline 発生確率 & 0.429 & 1.477 & - & - & 0.122 & 0.348 & - & - \\
\hline 被害想定の深刻さ & 0.467 & $1.849 *$ & 0.585 & $2.511^{* *}$ & 1.125 & $3.596^{* *}$ & 1.103 & $3.876^{* *}$ \\
\hline 災害の危険性 & 1.586 & $6.365 * *$ & 1.685 & $7.095 * *$ & 1.041 & $3.197 * *$ & 1.054 & $3.592 * *$ \\
\hline 反応効果 & 1.335 & 1.425 & - & - & 1.269 & 1.480 & - & - \\
\hline 自己効力感 & 0.805 & $2.640 * *$ & 0.886 & $3.161^{* *}$ & 0.043 & 0.129 & 0.139 & 0.464 \\
\hline 避難準備の面倒さ & 0.443 & 1.234 & - & - & -0.175 & 0.379 & - & - \\
\hline 避難移動の面倒さ & -0.180 & 0.527 & - & - & 0.269 & 0.562 & - & - \\
\hline 避難所生活の不快さ & 0.483 & $1.898^{*}$ & 0.458 & $2.084^{*}$ & 0.071 & 0.211 & 0.122 & 0.431 \\
\hline 自宅を留守にする不安 & -0.083 & 0.341 & - & - & 0.255 & 0.857 & - & - \\
\hline 尤度比 & \multicolumn{2}{|c|}{0.460} & \multicolumn{2}{|c|}{0.451} & \multicolumn{2}{|c|}{0.631} & \multicolumn{2}{|c|}{0.623} \\
\hline
\end{tabular}

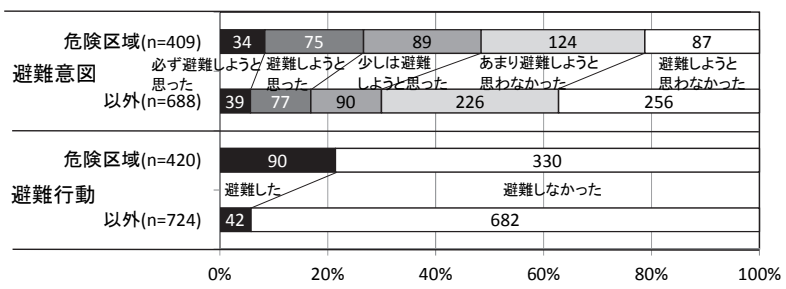

図-14 居住地の危険性と避難意図・行動

災害に対して危険な区域に居住しているグループほど， 避難意図や実際に避難する人の割合は多い。しかしなが ら，実際に避難した人は，災害に対して危険な区域に居 住している人の $21.4 \%$ であった. 豪雨時に特に生命の危 険性の高い土砂特別警戒区域（レッドゾーン）に居住し ている世帯は 14 世帯あったが，避難を実施したのは 6 世帯のみであり，4 世帯はあまり避難しようと思わなか ったと回答している.

\section{5. 避難意図と避難行動が乘離する原因の検討}

避難意図と避難行動が乘離する原因を総合的に検討す るために避難意図モデルと避難行動モデルを推定する.

ここで両モデルには，単純に「避難意図あり，なし」お よび「避難する, しない」を決定する二項選択型のロジ ットモデルを採用する．モデル推定にあたり，5段階の 避難意図を「必ず避難しようと思った」もしくは「避難 しょうと思った」を「避難意図あり」，それ以外を「な し」として取り扱っている. また，それらの意思決定す る説明要因として, 劦威評価を構成寸る要因, 非防護反 応を構成する要因, および対処評価を構成する要因を用 いる。.また，個人の減災行動に影響する諸要因からは，
「災害経験」と「避難経験」を用いる．地理的要件の居 住地点の危険性については, 予防的避難の呼び掛けシナ リオ 1 だけでは，十分なサンプルが得られなかったので ここでは考慮しない.

モデル推定にあたって, 大半の人が避難していないこ とを考慮し, 避難意図や避難行動の促進要因が検討でき るよう想定符号が正になるようにデータを設定した，具 体的には，脅威評価を構成する要因である「被害想定の 深刻さ」については，「全壊，もしくは，半壊」を1, その他を0，「災害発生確率」については，50\%以上を 1，その他を 0 ，「災害の危険性」については，「かな り感じる, もしくは, 感じる」を 1 , その他を 0 と設定 した. 非防護反応を構成するすべての要因について,

「どちらかといえばそう思わない，もしくは，そう思わ ない」を 1 ，その他を 0 と設定した. 対処評価を構成す る要因を構成する要因である「反応効果性」および「自 己効力感りについては，「そう思う，もしくは，どちら かと言えばそう思う」を 1 ，その他を 0 ，反応コストに 関わる 4つの要因については，「どちらかといえばそう 思わない，もしくは，そう思わない」を 1 ，その他を 0 と設定した.「被災経験」および「避難経験」について は，ともに「ある」を1に，「なし」を0に設定した。 避難意図および避難行動モデルのすべての説明変数候補 を採用してパラメータを推定した結果と避難意図モデル で統計的に有意となった説明変数のみでパラメータを推 定した結果を表-3 に示す，避難意図モデルで，有意と なった要因は，「避難経験」，「被害想定の深刻さ」，

「災害の危険性」，「自己効力感」および「避難所生活 の不快さ」の 5 要因であった.この結果から, 過去に避 
難経験があり，災害で自宅が被災したら被害が大きいと 思い，予防的避難の呼び掛けを聞いて身に危険を感じ， 自分で予防的避難を行うことが出来ると思っており，ま た, 避難所での生活は不快とは思わない人が避難意図が 高くなると推察される. 同じ要因を用いて避難行動モデ ルを推定したところ「自己効力感」および「避難所生活 の不快さ」の 2 要因が有意でなくなった。 したがって, 過去に避難経験があり，災害で自宅が被災したら被害が 大きいと思い，予防的避難の呼び掛けを聞いて身に危険 を感じた人が避難する傾向にあると推察される.

パラメータ推定結果から判断すると, 避難意図と避難 行動が乘離する要因は, 阻害要因が集約された負の定数 項が大きくなったことに加え，対処評価を構成する要因 の「自己効力感」および「避難所生活の不快さ」が避難 行動に影響しなくなったためである.いざ噼難となった とき, 自分で予防的避難を行うことが出来ると思うや避 難所での生活は不快とは思わないといった意識は, 避難 を促進する要因になりにくいことが推察される.

仮想的状況下での「避難意図」は高いにも拘わらず， 現実には避難行動を実施していない人が多数存在する. 自然災害に対寸る避難行動の場合, 時間的スケールから みると，この場合の避難意図は，日常の中での仮想的な リスクの回避・軽減行動の思考であり, 一方, 実際の避 難行動は非常時に判断を行うものである. 避難意図と実 際の避難行動の間に乘離が生じる要因は, 先述した心理 的コスト以外に非常時のリスク認知構造や意思決定過程 の構造が平常時とは異なっている可能性がある．例えば, 緊急時の意思決定は, 意思決定者のおか水ている状況や 環境, 文脈も重要であるという認識から, 状況条件を考 慮した意思決定の認知過程モデルが開発されている ${ }^{68770)}$. したがって，実際の避難行動を促していくためには，緊 急時の意思決定過程の構造を検討する必要がある.

\section{6. おわりに}

本研究では，まず，日本国内を対象とした既往研究の 中に見られる自然災害リスク認知や減災意識と防護行動 との乘離がある事例を抽出した. 自然災害リスク認知と 災害への備えとの間, 自然災害の知識やリスク認知と避 難行動との間に乘離がある事例を確認した．また，減災 行動における行動意図と実際の行動には乘離がある事例 もあった. さらに，被災経験が，災害時の避難行動を促 すとは限らないことを示した事例もあった。これらの事 例を通じて, 自然災害リスク認知のパラドックスの存在 を確認した. その上で，本研究では防護動機理論に基づ いて，個人の減災行動を説明するための基本的な枠組み
を構築し, 既往研究から減災行動や減災行動意図を促進 させる要因を抽出した.

阿蘇市および南阿蘇村における予防的避難の取り組み を事例に，防護動機理論に則った枠組みで，自然災害リ スク認知と避難意図, 避難行動との乘離および避難意図 と避難行動との乘離の要因を探った。

防護動機を形成するとされる要因と避難意図, 避難行 動の分析から下記の関係を示した。「被害想定の深刻 さ」が高い，「災害の危険性」を強く感じるからといっ て, 避難意図が高くなったり, 実際に避難するとは限ら ないことが確認された．また，避難を経験しているから といって避難するとは限らず，災害に対して危険な区域 に居住していても大半の住民は避難していない.このよ うに劦威評価の高い, もしくは, 高くなるような人でも, 避難意図が低く, 避難行動を取らない人が存在すること を明らかにした。

防護動機理論に基づく避難意図モデルから，避難経験 があり, 劦威評価の要因（被害想定の深刻さ，災害の危 険性）と対処評価の要因（自己効力感, 避難所生活の不 快さ）が高くなれば避難が促進される確率が高くなるこ とが示された．Rogers ${ }^{5}$ は，対処評価が低い場合に劦威 評価を高めても対処行動意図を削ぐ場合もあると指摘し ている，したがって，萵威評価に対応する自然災害リス ク認知と避難意図が乘離するパラドックスは，対処評価 を上げることや避難経験することにより解消が図れる可 能性がある. 避難経験が再度の避難行動を促す重要な要 因であることは，大本ら ${ }^{18}$ も指摘しており，彼らは，避 難訓練等により避難の疑似体験で避難経験に代わること を指摘している，一方，避難行動モデルでは，対処評価 が有意でなくなっており，上記の枠組みで避難行動を促 進できない可能性が示唆された。また, 避難意図と実際 の避難行動の乘離は, 両者の対処評価の評価構造の差異 に原因がありそうであることが分かった。これは，実際 の避難に伴う心理的コストや緊急時の意思決定過程の構 造が，仮想的な状況下でのリスク認知構造に違いがある ことが示唆される. 避難意図と実際の避難行動の乘離を 埋める要因を探ることは今後の大きな課題であるが，自 然災害リスク認知と避難意図および避難行動との乘離の 乘離の要因については，防護動機理論の対処評価の部分 を検討することにより，その乘離を埋められる可能性が ある。

\section{参考文献}

1) 内閣府: 平成 25 年度防災に関する世論調查, 2013 .

2) 内閣府: 平成 20 年度防災白書, 2008 .

3) Gisela, W., Ortwin, R., Chloe, B. and Christian, K. : The risk perception paradox - Implications for governance and communication of natural hazards, Risk Analysis, Vol. 33, No. 6, pp. 1049-1065, 2013. 
4) Dash, N. and Gladwin, H. : Evacuation decision making and behavioral responses: Individual and household, Natural Hazard Review, pp. 69-77, 2007.8.

5) Rogers, R. W. : A protection motivation theory of fear appeals and attitude change, The Journal of Psychology, Vol. 91, pp. 93-114, 1975.

6) Rogers, R. W. : Cognitive and psychological processes in fear appeals and attitude change: A revised theory of protection motivation, Social Psychophysiology (B. L. Cacioppo \& L. L. Petty Eds.), London, U.K., pp. 153-176, 1983.

7) Floyd, D. L., Prentice-Dunn, S., Rogers, R. W. : A metaanalysis of research on protection motivation theory, Journal of Applied Social Psychology, Vol. 30, pp. 407-429, 2000

8) 戸塚唯史, 早川昌範, 深田博己：環境ホルモン対処 行動意図に影響を及ぼす要因の検討一防護動機理論 の枠組みを用いて一，実践社会心理学研究，Vol. 41, No. 1, pp. 26-36, 2001.

9) 元吉忠寛, 高尾堅司, 池田三郎 : 家庭防災と地域防 災の行動意図の規定因に関する研究, 社会心理学研 究, Vol. 23, No. 3, pp. 209-220, 2008.

10) 高尾堅司, 元吉忠寛, 佐藤照子, 瀬尾佳美, 池田三 郎, 福直輝旗 : 住民の防㷋行動に及ぼす水害経験及 び水害予測の効果一東海豪雨災害の被災地域住民を 対象として一，防災科学技術研究所報告書，No. 63, pp. 71-83, 2002.

11) 上市秀雄，楠見孝：後悔がリスク志向・回避行動に おける意思決定に及ぼす影響 : 感情・パーソナリテ イ・認知要因のプロセスモデル，日本認知科学，Vol. 7, No. 2, pp. 139-151, 2000.

12) 今本博健, 石垣泰輔, 大年邦雄 : 昭 57.7 長崎水害に おける避難行動選択への影響要素について，自然災 害科学, Vol. 3, No. 1, pp. 22-33, 1984.

13) 今本博健, 石垣泰輔, 大年邦雄 : 昭和 58 年 7 月山陰 豪雨災害における住民の対応状況, 自然災害科学, Vol. 5, No. 1, pp. 9-19, 1986.

14) 原岡智子, 中井宏充, 尾島俊之, 野田龍也, 村田千 代栄, 早坂信哉：平常時における防災への知識・意 識・行動の関連, Journal of the National Institute of Public Health, Vol. 58, No. 3, pp. 277-282, 2009.

15) 斉藤徳美：1989 年三陸沖地震の津波に関する住民の 意識・行動解析, 自然災害科学, Vol. 9, No. 2, pp. 4963, 1990.

16) 古山周太郎，和田浩明：山間地域における被災状況 の異なる集落での避難行動と防災意識に関する研究 一紀伊半島大水害で被災した五條市大塔町の集落を 対象として一，都市計画論文集，Vol. 49, No. 3, pp. 621-626, 2014.

17) 木下猛, 青柳泰夫，伊藤孝司，平川了治，伊藤誠記， 安仁屋勉, 山本晶 : 風水害における避難行動に関す る避難プロセスについての一考察, 砂防学会誌, Vol. 63, No. 4, pp. 4-15, 2010.

18）大本照憲，藤見俊夫，小場隆太 : 河川災害における 住民の避難行動と災害外力の相関分析, 水工学論文 集, 第 52 巻, pp. 451-456, 2008.

19) 金井昌信, 片田敏孝, 阿部広昭：津波常襲地域にお ける災害文化の世代間継承の実態とその再生への提 案, 土木計画学研究・論文集, Vol. 24, pp. 251-261,
2007.

20）片田敏孝，及川康，杉山宗意：パネル調査による洪 水ハザードマップの公表効果の計測，河川技術に関 する論文集，Vol. 5, pp. 225-230, 1999.

21）览玉真, 片田敏孝, 桑沢敏行, 清水晃, 和田光広, 小林賢也：高潮災害時の広域避難実現に向けた住民 意思啓発に関する研究，土木学会論文集 B2, Vol. 69, No. 2, pp. 1356-1360, 2013.

22）及川康，片田敏孝：河川洪水時の避難行動における 洪水経験の影響構造に関する研究, 自然災害学会, Vol. 18, No. 1, pp. 103-118, 1999.

23) 山田忠，柄谷友香：水害リスクの受容と防災行動の 役割分担との関連性に関する研究一大垣市荒崎地区 を対象に一, 自然災害科学, Vol. 30, No. 4, pp. 441453, 2012.

24) 諫川輝之, 村尾修, 大野隆造 : 津波発生時における 沿岸地域住民の行動一千葉県御宿町における東北地 方太平洋沖地震前後のアンケート調査から一, 日本 建築学会計画系論文集, 第 77 巻, 第 681 号, pp. 2525-2532, 2012.

25）片田敏孝，木下猛，金井昌信 : 住民の防災対応に関 する行政依存意識が防災行動に与える影響, 災害情 報, No. 9, pp. 114-126, 2011.

26) 吉森和城，系井川栄一，梅本通孝：超高層集合住宅 における災害対応力に関する研究一平常時防災行動 の影響要因の検討一, 地域安全学会論文集, No. 14, pp. 111-121, 2011.

27) Rippetoe, P. A. and Rogers, R. W. : Effects of components of protection-motivation theory on adaptive and maladaptive coping with a health threat, Journal of Personality and Social Psychology, Vol. 52, pp. 396-604, 1987.

28) Grothmann, T. and Reusswig, F. : People at risk of flooding: Why some residents take precautionary action while others do not, Natural Hazard, Vol. 38, pp. 101-120, 2006.

29) Abraham, S. C. S., Sheeran, P., Abrams, D. and Spears, R. : Exploring teenagers' adaptive and maladaptive thinking in relation to the threat of HIV infection, Psychology and Health, Vol. 9. pp. 253-272, 1994.

30) Hodgkins, S. and Orbell, S. : Can protection motivation theory predict behavior? A longitudinal test exploring the role of previous behavior, Psychology and Health, Vol. 13, pp. 231-251, 1998.

31) Norman, P., Boer, H. and Seydel, E. R. : Protection motivation theory, In: Predicting Health Behaviour, Research and Practice with Social Cognition Models, Open University Press, Maidenhead, pp. 81-126, 2005.

32) Plotnikoff, R. C. and Higginbotham, N. : Protection motivation theory and the prediction of exercise and low-fat diet behaviors among Australian cardiac patients, Psychology and Health, Vol. 13, pp. 411-429, 1998.

33) Plotnikoff, R. C. and Higginbotham, N. : Protection motivation theory and exercise behavior change for the prevention of heart disease in a high-risk, Australian representative community sample of adults, Psychology, Health and Medicine, Vol. 7, No. 1, pp. 87-98, 2002.

34) Sarah, M., Orbell, S. and Paschal, S. : Combining motivational and volitional interventions to promote exercise participation: Protection motivation theory and implementation intentions, British Journal of Health Psychology, Vol. 
7, pp. 163-184, 2002.

35) Heller, K., Alexander, D., Gatz, M., Knight, B. and Rose, T. : Social and personal factors as predictors of earthquake preparation, The role of support provision, network discussion, negative affect, age, and education, Journal of Applied Social Psychology, Vol. 35, No. 2, pp. 399-422, 2005

36) Lindell, M. K. and Whitney, D. J. : Correlates of household seismic hazard adjustment adoption, Risk Analysis, Vol. 20, No. 1, pp. 13-26, 2000.

37) Schiff, M. : Hazard adjustment of control, and sensation seeking: some null findings, Environment and Behavior, Vol. 9, pp. 233-254, 1977.

38) Darrell, M. W. and Marion O. : Race, gender, and communications in natural disasters, The Policy Studies Journal, Vol. 35, No. 4, 2007.

39) Kellens, W., Zaalberg, R. N. T., Vanneuville, W. and Demaeyer, P. : An analysis of the public perception of flood risk on the Belgian coast, Risk Analysis, Vol. 31, No. 7, pp. 1055-1067, 2011.

40) Hassim, M. H. and Edwards, D. W. : Development of a methodology for assessing inherent occupational health hazards, Process Safety and Environmental Protection, Vol. 84, No.B5, pp. 378-390, 1993.

41) Russell, L., Goltz, J. D. and Bourque, L. B. : Preparedness and hazard mitigation actions before and after two earthquakes, Environment and Behavior, Vol. 27, pp. 744-770, 1995.

42）氏原岳人，阿部宏史，佐々木麻衣：津波に対する “備え” 特性の類似化と避難行動一の影響一津波非 常襲地域の居住者を対象として一, 都市計画学論文 集, Vol. 49, No. 1, pp. 120-127, 2014.

43) Drabek, T. E. : Social processes in disaster: Family evacuation, Social Problems, Vol. 16, No. 3, pp. 336-349, 1965.

44) Drabek, T. E. and Boggs, K. S. : Families in disaster: Reactions and relatives, Journal of Marriage and Family, Vol. 30, No. 3, pp. 443-451, 1968.

45) Heath, S. E., Kass, P. H., Beck, A. M. and Glickman, L. T. : Human and pet-related risk factors for household evacuation failure during a natural hazard, American Journal of Epidemiology, Vol. 153, No. 7, pp. 659-665, 2001.

46) Siegrist, M. and Gutscher, H. : Flooding risks, A comparison of lay people's perceptions and experts assessments in Switzerland, Risk Analysis, Vol. 26, No. 4, pp. 971-979, 2006.

47) 細井正延, 長尾正志, 広瀬幸雄, 羽鳥明満 : 水害経 験と防災意思との関係についての調查研究，自然災 害科学, Vol. 3, No. 1, pp. 33-43, 1984.

48) 宮瀬将之, 菊井稔宏 : 土砂災害における避難要因に つて, 砂防学会, Vol. 62, No. 3, pp. 55-61, 2009.

49) Ruin, I. Gaillard, J. C. and Lutoff, C. : How to get there? Assessing motorists' flash flood risk perception on daily itineraries, Environmental Hazards, Vol. 7, pp. 235-244, 2007.

50) Whitmarsh, L. : Are flood victims more concerned about climate change than other people? The role of direct experience in risk perception and behavioral response, Journal of Risk Research, Vol. 11, No. 3, pp. 351-374, 2008.

51) Botzen, W. J. W., Aerts, J. C. H. J. and van den Bergh, J. C. J. M. : Dependence of flood risk perceptions of flood risk perceptions on socioeconomic and objective risk factors, Water Resources Research, Vol. 45, pp. 1-15, 2009.

52）片田敏孝, 児玉真, 淺田純作 : 東海豪雨災害におけ る住民の情報取得と避難行動に関する研究，河川技 術論文集, Vol. 7, pp. 155-160, 2001.

53) Breznitz, S. : False alarms, Their effects on fear and adjustment, Issues in Mental Health Nursing, Vol. 7, No. 1- 4, pp. 335-348, 1985.

54) Dow, K. and Cutter, S. L. : Crying wolf, Repeat responses to hurricane evacuation orders, Coastal Management, Vol. 26, pp. 237-252, 1998.

55) Wachinger, G. and Renn, O. : Risk Perception and Natural Hazards, CapHaz-Net, Social Capacity Building for Natural Hazards Toward More Resilient Societies, 2010.

56) 奥村誠，塚井誠人，下荒磯司：避難勧告の信頼度と 避難行動, 土木計画学研究・論文集, Vol. 18, No. 2, pp. 311-316, 2001.

57) Walker, G., Whittle, R., Medd, W. and Watson, N. : Risk Governance and Natural Hazards, CapHaz-Net, Social Capacity Building for Natural Hazards Toward More Resilient Societies, 2010.

58）照本清峰，望月利男：地震情報に対する被害危険区 域住民の意識に関する分析, 土木計画学研究・講演 集, No. 23 (1), pp. 271-274, 2000.

59) Njome, M. S., Suh, C. E., Chuyong, G. and deWit, M. J. : Volcanic risk perception in rural communities along the slopes of Mount Cameroon, West-Central Africa, Journal of African Earth Sciences, Vol. 58, pp. 608-632, 2012.

60) Bird, D. K., Gisladottir, G. and Dominey-Howes, D. : Volcanic risk and tourism in Southern Iceland: Implications for hazard, risk and emergency response, education and training, Journal of Vocanology and Geothermal Research, Vol. 189, pp. 33-48, 2010.

61) 達川剛, 財賀美希, 藤井俊久, 松見吉晴, 太田隆 夫 : 住民の防災意識向上に有効な支援ツールの検証, 土木学会論文集 F6, Vol. 68, No. 2, pp. 175-180, 2012.

62）片田敏孝, 淺田純作, 及川康 : 過去の洪水に関する 伝承が住民の防災意識と対応行動に与える影響, 水 工学論文集, 第 44 巻, pp. 325-330, 2000.

63) 諫川輝之, 村尾修: 津波に対する住民の避難行動の 意向について空間的考察—千葉県御宿町を対象とし 一, 日本建築学会計画論文集, 第 75 巻, 第 648 号, pp. 395-402, 2010.

64）吉田護，柿本竜治：災害マネジメントフェーズを考 慮した住民の自助・共助・公助意識と減災行動, 都 市計画論文集, Vol. 49, No. 3, pp. 297-302, 2014.

65) 牛山素行: 大雨特別警報に対する洪水浸水想定区域 付近の住民の認識, 自然災害科学, 33 (特別号), pp. 75-86, 2014.

66) Kunhicke, C. et al : Perspectives on social capacity building for natural hazards: outlining an emerging field of research and practice in Europe, Environmental Science and Policy, Vol. 14, No. 7, pp. 804-814, 2011.

67 ) 柿本竜治, 金華永, 吉田護, 藤見俊夫 : 予防的避難 の阻害要因と促進要因に関寸る分析一防護動機理論 に基づいた予防的避難に関する意識構造分析一, 都 市計画論文集，Vol. 49, No. 3, pp. 321-326, 2014.

68) Lindell, M. K. and Perry, R. W. : Behavioral Foundations of Community Emergency Planning, Washington D.C.: 
Hemisphere, 1992.

69) Lindell, M. K. and Perry, R. W. : Communicating Environmental Risk in Multiethnic Communities, Thousand Oaks, CA: Sage, 2004.

70) Lindell, M. K. and Hwanq, S. N. : Households' perceived personal risk and responses in a multihazard environment, Risk Analysis, Vol. 28, No. 2, pp. 539-556, 2008.

(2016. 2. 26 受付)

\section{THE STUDY OF DISASTER RISK PERCEPTION PARADOX BASED ON PROTECTION MOTIVATION THEORY}

\section{Ryuji KAKIMOTO, Yasuaki UENO and Mamoru YOSHIDA}

It suggests the existence of a risk perception paradox that high risk perception does not always lead to personal protective actions. The existence of a risk perception paradox implies that it is not enough for promoting personal protective actions just to improve risk perception. The aim of this study inspects the existence of a risk perception paradox from an interdisciplinary review of previous studies about risk perception and behavioral response regarding natural hazards in Japan. Then, points and frames of the previous studies pigeonhole based on the protection motivation theory, and the comprehension of personal protective actions is stimulated. Further, the precautionary evacuation behavior in Aso area is analyzed based on the protection motivation theory and the factors of the gap between their risk perception and behavior is found. Consequently, if coping appraisal is low, it is confirmed that there are instances where personal protective actions are spoiled even if thread appraisal is high. Therefore it is indicated that improvement of coping appraisal has a potential to dissolve the risk perception paradox. 